Marquette University

e-Publications@Marquette

College of Education Faculty Research and

Publications

Education, College of

$5-1-2010$

Individual and Structural Orientations in Socially Just Teaching: Conceptualization, Implementation, and Collaborative Effort

Sharon Chubbuck

Marquette University, sharon.chubbuck@marquette.edu

Accepted version. Journal of Teacher Education, Vol. 61, No. 3 (May/June 2010): 197-210. DOI. (C) 2010 SAGE Publication. Used with permission. 


\title{
Individual and Structural Orientations in Socially Just Teaching: Conceptualization, Implementation, and Collaborative Effort
}

\author{
Sharon M. Chubbuck ${ }^{1}$ \\ College of Education \\ Educational Leadership and Policy Studies Department \\ Marquette University \\ Milwaukee, WI
}

\begin{abstract}
This essay, drawn from theory, research, and the author's practitioner research as a teacher educator, proposes a framework to inform teacher educators' conceptualization and implementation of socially just teaching. The framework suggests that building on dispositions of fairness and the belief that all children can learn, a socially just teacher will engage in professional reflection and judgment using both an individual and a structural orientation to analyze the students' academic difficulties and determine the cause and the solution to those difficulties, realizing that both individual and structural realities affect students' learning. The essay then suggests how this individual and structural framework can inform the content and teaching strategies teacher educators use to instruct preservice teachers in socially just education. Finally, recommendations for research and dialogue in the teacher education community are suggested.
\end{abstract}


NOT THE PUBLISHED VERSION; this is the author's final, peer-reviewed manuscript. The published version may be accessed by following the link in the citation at the bottom of the page.

Social justice is rapidly becoming one of those terms that is bleached of meaning while still able to evoke strong emotion. When that happens, the term can easily be co-opted, with its meaning filled in as the user sees fit. This frequently produces less clarity, with increased disagreement accompanied by strong emotions such as anger, defensiveness, and distrust. Not surprisingly, then, the wide use of the term social justice in teacher education (Zeichner, 2006) has produced an ample share of confusion and emotional reaction. For example, the number of justice-related presentations at the annual meeting of the American Educational Research Association has increased dramatically in the past several years, even as that array of presentations varies widely in practical implementation.

From outside the field, the popular press has leveled blistering criticisms against teacher education based on assumptions about how teacher educators define and teach socially just education. For example, John Leo's (2005) editorial in U.S. News \& World Report accused schools of education of imposing "group think" and a "culturally left agenda" associated with social justice. George Will (2006) argued in Newsweek for the closure of all schools of education because of the way they "discourage, even disqualify, prospective teachers who lack the correct 'disposition'" (p. 98) associated with social justice. In an editorial for City Journal, Stern (2006) described his impression of $\mathrm{K}-12$ schools with a social justice focus as places where "the idea of democratic empowerment for the students was subverting any hope for a rigorous education."

Such criticism understandably evokes caution about using the term social justice in teacher education units and their accrediting organizations; their cautious reactions, however, have then elicited further criticism from within our ranks. The National Council of Accreditation of Teacher Education (NCATE) has felt pressure from outside to omit the term in its documents with corresponding pressure from within to include it (Glenn, 2007), pressure intensified by the term's previously ill-defined link to dispositions (Sockett, 2009). This controversy has siphoned off energy to respond to the attacks in the popular press and to address wrangling among ourselves (Damon, 2005; Glenn, 2007; Leo, 2005; Sockett, 2009; Wise, 2006), energy that should be directed toward improving the quality of our profession.

Journal of Teacher Education, Vol. 61, No. 3 (May/June 2010): pg. 197-210. DOI. This article is (C) SAGE Publications and permission has been granted for this version to appear in e-Publications@Marquette. SAGE Publications does not grant permission for this article to be further copied/distributed or hosted elsewhere without the express permission from SAGE Publications. 
Indeed, the phrase social justice is becoming less practical and more divisive, to no one's benefit.

Caught in the cross fire, preservice teachers can end up parroting the phrase teaching for social justice with little substantive understanding, with varying degrees of conviction, and, consequently, with limited ability to act in the interests of greater justice. Too many abandon the notion altogether, whereas others ask, "Just what does teaching for social justice actually mean?" Though educational researchers and instructors have attempted to provide clarity, both practically (Bigelow, Harvey, Karp, \& Miller, 2001; Christensen, 2009; Cochran-Smith, 2004) and theoretically (North, 2006; Zembylas \& Chubbuck, in press), the confusion continues, frequently with more focus on individual teacher behaviors and less on the need to analyze and transform larger structural issues (Cochran-Smith, Shakman, Jong, Terrell, Barnatt, \& McQuillan, 2009; Whipp \& Chubbuck, 2009; Zeichner, 2006).

Confusion, however, also creates an opportunity for dialogue, leading to greater depth of understanding (North, 2006). At the risk of oversimplification, this essay attempts to enter into that dialogue by drawing from research, theory, and several years of personal reflection as a teacher educator. First, I suggest a framework for understanding social justice in education by attempting to clarify the links between dispositions, reflection, and teacher behaviors and the goal of social justice, using both an individual and a structural analytical lens. I then discuss how that framework can inform a practical implementation of socially just teaching and, in tandem, inform the strategies and approaches of teacher educators in their work with preservice teachers struggling to become socially just teachers. I conclude with suggestions for how this framework can inform future research and dialogue in the teacher education community.

\section{Conceptualizing Social Justice}

At a very simple, general level, we can understand social justice by thinking about its opposite-injustice. For example, an unjust society is one in which access to goods and opportunities deemed the essential human rights of individuals is limited or denied, with little or 
no recourse to rule of law or commonly held societal values. This limited access can be experienced either by an individual or by a group of individuals marked by some identifying characteristic such as race, class, gender, ability, or language. Even though strong disagreement about the meaning and implementation of the term social justice continues, few in this debate would argue in support of an unjust society (Prager, 2005; Wise, 2005), especially because the tenets of most major religions of the world include this view of justice.

The rub, then, comes not in questioning whether or not justice requires that all should experience fair and equitable access to essential human rights but in analyzing the cause of any unjust inequity and then, based on that cause, selecting an appropriate solution to create greater justice. Some would argue that the cause of inequitable access is best understood through analysis of the individual and thus should be resolved through individual efforts, such as acts of mercy, charity, or personal endeavor (Novak, 2000; Prager, 2005). Others would argue that the injustice that limits people's access to goods and opportunities exists because of structural inequalities, and thus addressing the injustice requires the transformation of those inequitable structures (Kincheloe, 2005; McLaren, 2003). Still others would argue that both individual and structural factors affect the level of justice, in fact feeding off each other, and thus both need attention (West, 1993).

Social justice in education parallels this argument. Nearly all would agree on the injustice of a school experience where any given child does not have equitable access to positive learning experiences and potential academic success, whether that inequity is because of the child's individual experiences or the child's experiences as a member of a specific sociocultural group. No one would argue in favor of a school with that inequity, and the virtually universal concern over the disheartening academic disparities among various groups of students bears witness to that fact. The source of disagreement, then, lies in deciding the cause of this inequitable experience of schooling and, based on how that cause is understood, the solution that will best create greater educational justice. The same individual and structural analytical lenses apply here. Will children experience a greater degree of access to educational knowledge, skills, and success when teachers 
analyze the causes of and solutions to inequity through an individually oriented lens? Or are the chances of children's educational success greater when teachers view these issues through a structurally oriented lens? Or does some combination of these two perspectives provide the greatest hope of an increasingly just educational experience for all children?

This reasoning and these accompanying questions produce a definition of socially just teaching with three parts. First, and least controversial, socially just teaching comprises those curricula, pedagogies, and teachers' expectations and interactional styles that will improve the learning opportunities (and, by implication, life opportunities) of each individual student, including those who belong to groups typically underserved in the current educational context (Cochran-Smith, 2004; Delpit, 1995; Ladson-Billings, 1994). Second, and slightly more controversial, socially just teaching also includes the transformation of any educational structures or policies that diminish students' learning opportunities. Socially just teachers understand how structural inequities of schools can impede student learning, and they will challenge and, ultimately, work to transform those structures (Carlisle, Jackson, \& George, 2006; Kincheloe, 2005; McLaren, 2003; Nieto, 2000), including everything from teacher demographics to funding disparities to policies that affect student learning. Third, and most controversial, socially just teachers recognize the need to look beyond the school context and transform any structures that perpetuate injustice at the societal level as well (Giroux, 1988; Kincheloe, 2005; McLaren, 2003). They will act for this transformation; they will also provide curriculum and instruction that challenge all their students to envision themselves as active citizens with the power to transform unjust structures (Carlisle et al., 2006; Christensen, 2009; Freire, 1970). As Westheimer and Kahne (1998) describe, socially just teaching fosters students' "ability to work collectively toward a better society" through an unabashed commitment to "fostering the attitudes, skills and knowledge required to engage and act on important social issues" (p. 2).

Although these three components of socially just teaching can be controversial in themselves, even more controversy has come from the muddy connections between "social justice" and the dispositions 
identified by NCATE as necessary for effective teaching. In NCATE documents, social justice was originally included in the "values" (along with caring, fairness, honesty, and responsibility) that are related to dispositions deemed desirable in teachers (NCATE, 2006). This confusing, even though indirect, placement of social justice in the definition of dispositions (Burant, Chubbuck, \& Whipp, 2007) drew fire from the popular press when teacher education programs attempted to assess preservice candidates' dispositions in ways similar to the assessment of their knowledge and skills (Gershman, 2005). Under that attack, NCATE officials eventually removed the term social justice from their glossary entirely (Powers, 2006) and currently name two desirable professional dispositions for teachers: "fairness and the belief that all students can learn" (NCATE, 2009). In that revision, individual teacher education programs can choose other dispositions, including social justice, that they identify as desirable, which they can then assess through observable, measurable behaviors. The relationship between dispositions and social justice needs more attention, however.

Sockett (2009) offers some of that attention when he defines social justice as a goal of education rather than a disposition. In his view, a fairly stable body of desirable dispositions (or virtues) may be identifiable; different goals of education such as social justice, then, can be selected locally, relative to the vision or mission of each particular teacher education program. However, the confusion over the link between social justice and dispositions is not alleviated that simply because the issue can be understood through an examination of syntax as well as through a discussion of substance. For example, social justice is a noun (a circumstance or condition) and the dispositional description of one working for that circumstance is an adjective-a socially just person-in the same way that fairness is a noun (a circumstance or condition) and the dispositional description of those working for fairness also is an adjective-fair teachers.

Simply put, the circumstance of social justice is indeed a goal (noun), yet some description (adjective) of the individual valuing that goal can be named, regardless of whether that description is understood as a disposition per se or an orientation toward the teaching context; the presence of that descriptor can then be measured by observable behaviors (verbs or nouns) that produce the permission has been granted for this version to appear in e-Publications@Marquette. SAGE Publications does not grant permission for this article to be further copied/distributed or hosted elsewhere without the express permission from SAGE Publications. 
desired goal, completing the circle. For those teacher education units that identify social justice as integral to their vision, then, simply separating social justice from dispositions is not helpful. Rather, we must attempt to understand the nature of the winding pathway that links dispositions, behaviors, and goals if we are to support preservice and in-service teachers in their pursuit of the goal of social justice in education.

\section{Framework for Socially Just Education}

\section{Rudimentary Connections}

To understand that connection and create a working framework of socially just education, let us begin with NCATE's (2009) current description of the two basic dispositions for teachers: fairness and a belief that all children can learn. The assumption is that these two dispositions will prompt teachers to adopt policy, curricular, and instructional practices leading to equitable learning experiences for all students, a goal congruent with this essay's first component of socially just teaching. The disposition of fairness toward each individual student, initially expressed in a desire to see each child succeed, is commonly found in many preservice teachers (Chubbuck, Burant, \& Whipp, 2007; Cochran-Smith et al., 2009; Whipp \& Chubbuck, 2009). The belief that all children can learn, the opposite of a deficit view of students, may or may not be as prevalent.

At the most rudimentary level, these dispositions link in an uncomplicated, linear manner to behaviors that will produce the desired goal of equitable education. Diez (2007), Dottin (2009), and Sockett (2009) all describe how closely dispositions (habits of mind, moral sensibilities, virtues) are connected to the goals of education; that connection does not, however, demand or predict the use of specific methods to reach those goals. The choice of methods is derived from a process of professional reflection and judgment (Dottin, 2009), often explored via dialogue in a "community of professional practice" (Diez, 2007, p. 395).

Figure 1 illustrates this basic process. A teacher marked by dispositions of fairness and a belief that all students can learn will see

Journal of Teacher Education, Vol. 61, No. 3 (May/June 2010): pg. 197-210. DOI. This article is @ SAGE Publications and permission has been granted for this version to appear in e-Publications@Marquette. SAGE Publications does not grant permission for this article to be further copied/distributed or hosted elsewhere without the express permission from SAGE Publications. 
a student struggling to learn to read, engage in professional reflection about that struggle, and decide that the cause of the academic struggle is the student's lack of content understanding and essential skills. Based on that identified cause, the teacher will then decide on a solution, such as selecting curriculum and methods to teach the missing content and skills.

\section{Individualistic Orientation in Professional Reflection}

Teachers' decision-making processes seldom remain at that rudimentary level, however. Simply analyzing that a student lacks the necessary content and skills to be able to read proficiently is too simplistic and, ultimately, unhelpful in its sweeping generality. Another analytical step typically occurs: Beyond analyzing that missing content and skills are causing the student's struggle to read, teachers also professionally reflect on the deeper cause that explains why those skills and content are missing. At this point, the teacher can use either an individual or a structural orientation in the reflection process, each producing potentially different understandings of causes and, consequently, different choices of solutions.

When this next level of analysis is done with an individual orientation (see Figure 2), the teacher analyzes why the struggling student is missing skills and content by primarily focusing on the individual child's experiences; with this individual orientation several interpretations and responses are possible. The teacher may decide that the student is missing skills or content because of flaws in the child's family and community and/or the child himself or herself. Based on that analysis of deficiency as the cause of the learning difficulty, the teacher can then select different responses and solutions. One, the teacher may reject the disposition of believing all children can learn, blame the student and his or her environment, and essentially give up on helping the child learn; after all, if the cause of the academic struggle lies outside the realm of the school's and teacher's influence, that is, in pathological behaviors of student, families, and communities (e.g., the family doesn't value education, the child is lazy, the community doesn't support learning), the teacher has relatively little power to apply a solution to change that outside cause. 
Even though this deficit view can become a generalized stereotyping of the child's experiences as a member of a specific group-that is, thoughts that "poor children are ..." or "English language learners are ..."-the perspective often remains essentially individualistic because at its heart is a belief that any individual in these groups, by virtue of personal character, talent, and effort, can pull himself or herself out of the academic struggle and learn to succeed. An alternative and slightly more positive solution, however, may also be available to the teacher who adopts this deficit view of the student or even entire groups of students (see Figure 2). Rather than abandoning the child who is perceived as the deficit, the teacher may decide that the solution lies in "fixing" the deficits of the child by providing the needed content and skills instruction. Although this solution keeps the teacher engaged with the student and might produce greater learning, the teacher may still maintain a deficit view of the student and a savior view of himself or herself, both with potentially negative effects on the child.

Another interpretation and set of responses, however, are possible for the teacher applying an individual orientation to the process of professional reflection and judgment (see Figure 2 ). The teacher can locate the cause of the student's academic struggle in the individual school experiences of the student. The necessary skills, knowledge, and readiness that are needed for the child to read are missing because of unique, individual school experiences-prior classroom interactions, mismatched instruction or learning pace, inadequate or ineffective content instruction, student and teacher personality or style conflict, and so on. Based on this analysis, also grounded in dispositions of fairness and the belief that all children can learn, the teacher sees these school experiences as relatively neutral, value-free causes of the child's academic struggles that do not necessarily lead to a deficit view of the student, the family, or the community.

Based on these neutral school-based causes, the teacher then selects solutions to address this need, choosing from a wide variety of reasonable practices, selecting those that seem to best meet the individual student's need such as sound-symbol instruction, wholelanguage instruction, balanced literacy instruction, and/or reading 
recovery support. In this same analysis, the teacher may also decide that the content and skills are missing because of individual learning challenges the student faces, such as previously unidentified special education needs or language interference. Again, based on the dispositions of fairness and the nondeficit conviction that all children can learn, the teacher will seek out the necessary academic support and resources to address these individual needs and then supply knowledge and skill instruction.

\section{Individualistic and Structural Orientation in Professional Reflection}

In the best options of the above scenario, the teacher's professional judgment using an individual orientation leads to the appropriate resources and curricular or instructional decisions to support the child's learning. The possibility of adopting a deficit view of the students, families, and communities remains, however, with potentially negative effects. Adding a structural orientation to the professional reflection or judgment process provides expanded and different interpretations that may help diminish the danger of a deficit view of students and open up a wider range of possible solutions for improving students' learning and life opportunities.

Adding a structural orientation to the professional reflection process does not cancel out the need to respond to the student's individual needs; rather, this additional orientation complements and builds on the former (see Figure 3 ). The teacher using both individualistic and structural perspectives will see the student who is struggling to read both as an individual with unique experiences and as a member of a larger sociocultural group that may have experienced structural, institutional barriers to learning. The teacher will still identify individual causes of the student's lack of knowledge and skills and then select solutions to address those individual causes, including seeking additional academic support and resources to provide instruction on the missing elements. With the additional structural orientation in the reflective process, however, the teacher also may identify and respond to the larger structural inequities within the educational system that may have affected the child's ability to succeed.

Journal of Teacher Education, Vol. 61, No. 3 (May/June 2010): pg. 197-210. DOI. This article is (C SAGE Publications and permission has been granted for this version to appear in e-Publications@Marquette. SAGE Publications does not grant permission for this article to be further copied/distributed or hosted elsewhere without the express permission from SAGE Publications. 
For example, the child may have had inequitable access to learning because of the lack of proportionate racial diversity in the teaching force (Zeichner, 2006), the frequently negative effects of tracking on children of color and of poverty (Braddock, 1995; Gamoran, 1992; Oakes, 1985), the lack of validity in standardized tests for many negatively stereotyped groups (Steele, 1997), the disempowering effects of a mono-cultural curriculum (Banks, 2007a), the lack of culturally congruent pedagogy (Ladson-Billings, 1994; Lee, 2007), the absence of adequate bilingual education (Collier \& Thomas, 2004), and the limiting effects of inequitable funding (Biddle $\&$ Berliner, 2002; Kozol, 1991). Using both an individual and a structural orientation in the reflection process, the teacher can see how the student's struggle to learn to read may be because of both individual experiences and structural inequities in the school (see Figure 3 ). With this structural orientation, the teacher may also be able to identify inequitable structures in society, frequently linked to race, class, and gender, such as differential access to employment, housing, transportation, and health care. These structural issues reproduce inequity for various sociocultural groups, including negatively affecting a child's learning experiences. Looking beyond the bounds of the educational system for causes of and solutions to inequity, the teacher can then assume an advocacy or activist role that challenges these societal-level issues.

A combined individual and structural orientation in the professional reflection process can give teachers a much richer understanding of the learning challenges the child faces. Simply put, the obstacles to learning identified using an individual lens and the obstacles identified through analyzing structural inequities interact to multiply each other's effects, with significantly negative consequences on the child's possibility for academic success. Societal- and schoollevel structural inequities influence the child's individual experience of instruction-hungry children are not as receptive to reading instruction, and English language learners struggling with inadequate support in language instruction will be less successful readers. Similarly, the student's individual achievement experiences will feed back into his or her experience of school with implications for societal structures-unsuccessful readers will fall further behind in all content permission has been granted for this version to appear in e-Publications@ Marquette. SAGE Publications does not grant permission for this article to be further copied/distributed or hosted elsewhere without the express permission from SAGE Publications. 
areas, ending up in lower level tracks with fewer opportunities for mastery of higher level knowledge and skills and, ultimately, with fewer opportunities for higher education and economic advancement.

The teacher who analyzes the child's learning experience through both an individual and a structural orientation will be better equipped to supply the support and instruction that the child needs individually and to begin to redress the effects of and transform the realities of educational and societal structures that perpetuate learning inequity. This richer, more nuanced understanding of the student's needs, based on the interactive nature of both individual and structural experiences, can support the development and application of a richer repertoire of curricular, pedagogical, and policy responses to address the child's needs.

Equally important, analyzing a student's academic struggles with both an individual and a structural orientation may allow the teacher to see the strength and resilience of the student struggling to learn in the face of larger structures that impede learning, a potentially positive antidote to the development of a deficit view of the student. Furthermore, in that more positive framing of the student, the teacher can invite all students to join in critical study and action regarding inequities in school and societal structures. As teachers become advocates for policy change, they can provide curriculum and pedagogy that can empower their students to join them in becoming proactive agents, engaged in civil discourse and transformative action around significant social issues (Bigelow et al., 2001; Freire, 1970; Parker, 2005). Westheimer and Kahne (2004) describe these students as "justice-oriented citizens" who seek greater equity through structural, institutional reform, including but moving beyond individualistic levels of mercy or service.

The scenario described above is admittedly quite hopeful; indeed, hopefulness is easy in a theoretical description of how various orientations applied to the reflection process may have positive effects on teachers' beliefs and practices. The theorizing of this framework has emerged from years of practitioner research-pedagogical selfstudy of my own practice as a teacher educator, engaging in professional reflection on my preservice teachers' struggles to 
understand and implement socially just teaching, and adjusting my curriculum and instruction based on that reflection. It has not been tested by studying student learning outcomes in the actual practice of teacher candidates once they enter the field. And though I have seen some positive effects in my preservice teachers, I know that this framework of both an individual orientation and a structural orientation will not magically eradicate all deficit views of children and automatically transform preservice teachers into practitioners who embrace and successfully implement socially just teaching. This framework is clearly not a predictive model grounded in extensive empirical research.

In reality, however, no theoretical framework can accurately predict or prescribe the general beliefs and behaviors of pre- and inservice teachers. The added complexity of social justice only increases the pitfalls and surprising twists in the teaching experience. I do not claim that this framework will guarantee that teacher educators, preservice candidates, or inservice teachers will safely navigate socially just teaching and avoid those pitfalls or anticipate and adjust for all those twists and turns. Rather, I offer the framework to inform our understanding of socially just teaching and to provide possible direction to guide our instruction and implementation of that understanding.

This framework offers greater clarity of the construct of socially just teaching through a logical explication of the links among dispositions, reflection, behavior, and the goal of socially just education, an explication that has, as yet, been undeveloped in the discussion. In that explication, the use of both individual and structural analytical lenses potentially offers preservice and inservice teachers a wider array of explanations of learning difficulties and, consequently, the possibility of lessening the level of deficit views of students and their families or communities. In addition, the wider array of explanations also may open a greater range of possible solutions to adopt to improve student learning. The next section describes some of those practices and suggests methods available to teacher educators to support preservice teachers' exploration of them. permission has been granted for this version to appear in e-Publications@Marquette. SAGE Publications does not grant permission for this article to be further copied/distributed or hosted elsewhere without the express permission from SAGE Publications. 


\section{Implementing and Teaching Socially Just Education With Individual and Structural Orientations}

This framework creates a schema that may help teacher educators conceptualize and teach a more socially just practice for their preservice teachers to implement. It utilizes the rich and ongoing interaction of the individual and structural to fill that schema with implications for the classroom teacher, his or her students, and the world beyond the classroom. Using the planning technique of "mapping backward" (Wiggins \& McTighe, 2005), I describe the goal, that is, the practice of the socially just teacher as I conceive it, and then suggest a few teaching strategies teacher educators can use to support preservice teachers in their exploration and mastery of that goal.

These strategies are drawn from my own experiences in teacher education. As in most preservice teacher programs, my classes are overwhelmingly populated by White, middle-class preservice teachers. When we are fortunate enough to have a class member who is a member of a racial or socioeconomic group other than the majority, their perspectives in these activities or discussions frequently enrich the learning experience. Some of the strategies have worked fairly well with some of the preservice teachers; none of them work all the time with all the students. Such is the nature of teaching. I offer these strategies, then, as suggestions with anticipation of learning many more strategies from my fellow teacher educators as dialogue on this topic continues.

\section{Implications for Teachers}

Teachers for social justice are, first, those who have engaged in a deep, profound, and, frequently, painful process of individual selfreflection to become holistically more just people; this process often requires a lifelong commitment (Chubbuck, 2004; Darling-Hammond, 2004). Just teaching practices inherently originate in a rigorous selfexamination where personal biases and emotional responses are brought into the light of self-awareness, accompanied by a humility of heart that is willing to admit their presence and to do the work needed to address them productively (Chubbuck, 2004; Chubbuck et al., 2007). This process is ultimately a deeply personal, individualistic

Journal of Teacher Education, Vol. 61, No. 3 (May/June 2010): pg. 197-210. DOI. This article is (C SAGE Publications and permission has been granted for this version to appear in e-Publications@Marquette. SAGE Publications does not grant permission for this article to be further copied/distributed or hosted elsewhere without the express permission from SAGE Publications. 
experience, even when it occurs in the context of a community of preservice or inservice teachers. Each must struggle with his or her own emotional responses to questions of injustice and personal bias (Chubbuck \& Zembylas, 2008). Teachers who are members of the dominant culture may deal with personal emotional demons (Dlamini, 2002), such as guilt, depression, anxiety, and powerlessness, that frequently are associated with teaching for social justice (Berlak, 2004; Chubbuck, 2008; Chubbuck \& Zembylas, 2008). Teachers of color often must personally process a different range of emotions, often including anger, frustration, and discouragement over being marginalized and silenced in school discourse about educational practices with students of color (Delpit, 1995; Lipman, 1997).

As teacher educators, we must not underestimate the individual emotional labor required in this process, or we may fail to provide adequate support for our students (Chubbuck, 2008; Chubbuck \& Zembylas, 2008). Based on my experience, one valuable strategy to support this emotional self-examination is to normalize the process. This can be done in several ways. One, I tell my own story as a White woman engaged in an ongoing process of understanding the nature of racism, sexism, and classism in society and in myself. I share the pain I felt and the lesson I learned when a colleague of color "called me out" for expecting her to enlighten my White ignorance of racial injustice. I also share how another colleague of color gently revealed the emotional pain of her near daily experiences of stereotyping and discrimination and the guilt I felt that I had known and worked with her for years with very little consideration of her reality in a racially stratified society. I emphasize that my learning of these issues continues to the present.

Second, I tell my preservice teachers not to fear these painful emotions that will be evoked in their education but to learn from them and move forward. I tell them what a teacher in one of my research projects said when she realized that, once more, she was expressing a racist blind spot: "I was sick and now I'm getting better, I was in the dark and someone turned on a light for me" (Chubbuck, 2001). The preservice teachers write reflective journals where they discuss their emotional responses to what they are learning about injustice, reflect on how these intersect with their ethical or spiritual values, and permission has been granted for this version to appear in e-Publications@Marquette. SAGE Publications does not grant permission for this article to be further copied/distributed or hosted elsewhere without the express permission from SAGE Publications. 
consider possible changes in behavior because of these cognitive, affective, and ethical experiences. By normalizing the process through inviting honest discussion of the emotions and through engaging the whole person-cognitive, affective, ethical or spiritual, and behavioral (Chubbuck, 2001)-I am able to support some students in this process of personal self-reflection and interrogation.

In spite of its individual nature, however, this process requires a profoundly structural understanding and analysis as well. The growing racial and cultural disparity between the current student population and the teachers who work with those students is creating a "demographic imperative" (Banks, cited in Cochran-Smith, 2003) where White, middleclass teachers working with a culturally and racially diverse student population need, at bare minimum, a level of awareness of their own and their students' racial and cultural identity and of how those can intersect in the classroom.

Even more, however, White, middle-class teachers need to critically examine how societal structures have shaped their and their students' experiences (Darling-Hammond, 2004) in numerous arenas-educational, political, economic, social. Those structures frequently award privileges and limit access on the basis of membership in racial, gender, and socioeconomic groups. When preservice teachers begin to recognize how power and privilege are dispensed differently to different groups of people, when they start to realize that they too are part of that inequitable distribution, many are in a better position to consider enacting a more socially just teaching practice as defined in this essay. Indeed, even the emotions educators experience as individuals operate as constitutive, politicized entities that either support or transform inequitable structures of power and privilege-such as which emotions are "allowed" for which groups of people and how individuals are emotionally attached to and then perpetuate cherished beliefs such as meritocracy (Boler \& Zembylas, 2003; Chubbuck \& Zembylas, 2008; Zembylas \& Chubbuck, in press).

The challenging task, then, is helping mainstream preservice teachers learn to see outside the blinders of their personal racial, cultural, or socioeconomic experience to identify how structurally imposed privilege and discrimination have affected both their and their permission has been granted for this version to appear in e-Publications@Marquette. SAGE Publications does not grant permission for this article to be further copied/distributed or hosted elsewhere without the express permission from SAGE Publications. 
future students' lives. In a course analyzing schooling policies through the lenses of race, class, gender, and language, I begin the semester with a discussion of the importance of teachers constantly seeing themselves and their students as both individuals with unique experiences and as members of groups with a set of common experiences. I ask my preservice teachers to reflect on the level of individual hard work they exerted to be able to come to the university, an exercise most of them thoroughly enjoy and readily own. I then ask them to name the support they had in coming to the university, including financial resources, social networking, precollege educational opportunities, and cultural capital to negotiate the maze of ACT and SAT test preparation, application steps, and Free Application for Federal Student Aid forms. Finally, I ask them to reflect on how equitably those supportive resources are distributed in society.

This simple exercise begins the process of helping them see that both individual efforts and structural resources are realities that call into question a belief in a straightforward, objective meritocracy. That dialectic, of both individual and structural experiences, is then applied throughout the rest of the course in light of the preservice teachers' racially, socioeconomically diverse field placements, as we regularly juxtapose the stories of the individual students they meet with statistics of how different racial, gender, socioeconomic, and language groups experience various educational policies.

\section{Implications for Students}

\section{Pedagogy}

The practice of socially just education with the students in the K-12 classrooms also requires both an individual and a structural orientation. The list of pedagogical practices that can offer more equitable access to learning for all students is quite long, with most of those practices rightly understood simply as good teaching that is applied to each individual student. That statement captures the heart of the first component of social justice education: All children deserve equal access to equitable learning experiences, and that requires thorough content knowledge and effective pedagogical content knowledge (Shulman, 1986) -in other words, good teaching. Cochran- 
Smith (2004), in her description of the principles of socially justice education, makes this quite clear because much of what she lists can be described as good teaching conducted in response to the learning experiences of individual students in the classroom.

Quite simply, justice means that the children entrusted to our care learn to read, write, do math, and understand science and social studies proficiently. The decisions concerning which pedagogical tools to use to support a child's learning will emerge first from an understanding of the individual student. As described earlier (Figure 2 ), a teacher must decide on the reasons why an individual student has failed to master reading and then choose solutions, ranging from instruction in sound-symbol correspondence to whole-language immersion in text. Justice demands that the individual students in our care master the high-status knowledge and skills required for them to continue their academic careers and eventually function as contributing citizens in a democratic society and a globalized world. To offer them less is a profound act of injustice.

Yet the learning of individual students in $\mathrm{K}-12$ classrooms also is affected by their membership in sociocultural groups as well as by the school and societal structures that support or impede the education of those groups; socially just teaching must acknowledge and account for that reality. That is why Banks (2007b) calls for the development of "equity pedagogy" (p. 22), with an understanding of these larger cultural and structural implications, to facilitate the learning of diverse students. Growing out of a vision of cultural difference as strength rather than deficit (Banks, 2007b; Cochran-Smith, 2004) and an appreciation for the "funds of knowledge" (Moll, 1994) available in students' families and communities, equity pedagogy utilizes instructional methods that build on the cultural knowledge, norms, and communicative practices of students.

These methods include culturally relevant pedagogy that maximizes the learning potential found in students' cultural resources (Au, Mason, \& Scheu, 1995; Delpit, 1995; Ladson-Billings, 1994; Lee, 2007; Moll, 1994), instruction that is responsive to different learning styles (Banks, 2007b), communication that attends to cultural and linguistic differences (Au et al., 1995; Delpit, 1995; Heath, 1882; permission has been granted for this version to appear in e-Publications@Marquette. SAGE Publications does not grant permission for this article to be further copied/distributed or hosted elsewhere without the express permission from SAGE Publications. 
Perry \& Delpit, 1998), and a variety of instructional strategies that support constructivist, cooperative learning (Bigelow et al., 2001; Cochran-Smith, 2004; Darling-Hammond, 2004). In conjunction with these pedagogical elements, socially just teachers collaboratively engage with the community, recognizing the partnership they share in the education of the children (Carlisle et al., 2006; Cochran-Smith, 2004). They also use multiple and varied assessments to provide both summative and formative feedback on student learning (CochranSmith, 2004; Garcia \& Pearson, 1991).

Many of the aforementioned elements of good teaching and equitable pedagogy are the meat and potatoes of methods courses in teacher education. Teaching those methods can be enhanced by placing preservice teachers in racially, culturally, and socioeconomically diverse field placements where their theoretical knowledge of the importance of including individual and structural orientations in their professional reflection can be put into practice. Equally important, however, is the support of a cooperating teacher and university supervisor who will both model and support the equity pedagogy that socially just teaching requires.

\section{Curriculum}

The interplay of the individual child and the child as a member of a sociocultural group also affects the curricular choices a socially just teacher makes. This has three components. Students need curricular content that is reflective of their experience. They also need access to mastery of the high-status knowledge and skills that will open academic and professional opportunities for them. And finally, they need to explore curriculum that allows them to discover their own power to deconstruct oppressive systems and to envision possible futures previously unimagined. When discussing this with my preservice teachers, I use the metaphor that the curriculum socially just teachers choose will offer their students a mirror, a tool kit, and a window. Determining what these curricular components actually look like depends on knowing their students individually and, at the same time, recognizing, welcoming, and honoring the larger group identity and structural experiences that have continual influence on their lives.

Journal of Teacher Education, Vol. 61, No. 3 (May/June 2010): pg. 197-210. DOI. This article is (C SAGE Publications and permission has been granted for this version to appear in e-Publications@Marquette. SAGE Publications does not grant permission for this article to be further copied/distributed or hosted elsewhere without the express permission from SAGE Publications. 
A curriculum as mirror uses "students' lives as critical texts" (Christensen, 2009, p. 1), where both the texts and the products of the class are centered on students' experiences and communities. Though improvement in balanced representation has been made in many textbooks, the contributions and experiences of women, working-class people, and people of color are still inequitably represented (Landsman, 2009). Without that mirror to reflect student identity, learning will be thwarted. Poet Adrienne Rich (1986) captures this in her statement:

When those who have the power to name and to socially construct reality choose not to see you or hear you, whether you are dark-skinned, old, disabled, female, or speak with a different accent or dialect than theirs, when someone with the authority of a teacher, say, describes the world and you are not in it, there is a moment of psychic disequilibrium, as if you looked into a mirror and saw nothing.

The absence of a curricular mirror will be experienced differently by individual students; that the curriculum underrepresents specific groups, however, clearly indicates that teachers need to grasp the importance of a larger, structural orientation toward the curriculum.

Curriculum also needs to function as a tool kit for students, offering each of them individual access to the high-status knowledge and skills that serve as gatekeepers to levels of higher learning and professional success. As Cochran-Smith (2004) describes, socially just teachers instruct students in the skills needed to "bridge gaps" (p. 70) in their academic performance. The mastery of written and spoken standard English; knowledge of science, literature, and history; and skilled understanding of math and technology all serve as the tools students will need to move forward as successful learners and citizens. Gaining that mastery represents neither a moral improvement (Erickson, 2007) nor the acquisition of a set of skills and knowledge inherently better than others (Delpit, 1995); however, mastery or lack of mastery of that set of skills will create an academic and life trajectory for our students with significant material effects. Consequently, a curriculum that does not give each student individual access to these tools is not just. permission has been granted for this version to appear in e-Publications@Marquette. SAGE Publications does not grant permission for this article to be further copied/distributed or hosted elsewhere without the express permission from SAGE Publications. 
Though professional reflection on how best to support students' mastery of knowledge and skills may first be informed by an individual orientation, the teacher needs to take into consideration how the students of various sociocultural groups approach their learning with their own community and cultural body of knowledge and skills as well as specific language or communication practices. These must not be denigrated as students learn other bodies of knowledge and skills; rather, they need to be incorporated to improve the effectiveness of instruction. For example, Lee (2007) describes teaching based on cultural modeling that successfully supports African American students' ability to do literary analysis. In this method, students and teacher create and apply a heuristic (e.g., an expanded definition of symbolism) first to a cultural text (e.g., Iyrics to the Fugees' rap song "The Mask"), then to a text reflective of the students' cultural and racial group (e.g., Toni Morrison's Beloved), and finally to a text from the traditional canon. In this process, the cultural knowledge and communication styles of the students are used to build their understanding of the symbolism and, consequently, their ability to analyze all literature.

Another way to incorporate students' culturally specific knowledge in instruction is to utilize students' home language as a tool for learning, not a detriment to learning. In earlier research, Taylor (1989) found that African American college students' use of written standard English improved significantly when they were taught to compare and contrast African American English with standard English in neutral, nonevaluative ways-they are simply different and each applicable in different contexts - in comparison to those taught in the traditional, evaluative manner-standard English is right, any deviation is wrong. Similarly, even earlier work by Piestrup (1973, cited in Rickford, 1997) found that African American first graders' reading significantly improved when teachers positively responded to children's rhythm and speech patterns, helping them see differences between their speech and standard English, compared to the teachers who interrupted students to correct their pronunciation. These findings are reflected in the recent work of Wheeler and Swords (2006), who saw significant academic improvement when they used contrastive analysis with African American elementary students, teaching them to permission has been granted for this version to appear in e-Publications@Marquette. SAGE Publications does not grant permission for this article to be further copied/distributed or hosted elsewhere without the express permission from SAGE Publications. 
recognize the differences between their home language and standard English, not as incorrect and correct but as different and each appropriate with specific audiences and contexts.

These student resources-cultural knowledge and home language skills-exist in the context of unjust structural realities, including a long history of Eurocentric curricula, frequently accompanied by a denigration of the culture and language of nondominant groups. Introducing preservice teachers to the research of scholars such as Lee (2007), Taylor (1989), Piestrup (cited in Rickford, 1997), Wheeler and Swords (2006) can help them challenge those negative attitudes and structural barriers to students' learning as well as provide them with instructional strategies that will benefit individual students. Socially just teaching foundationally must help students master the skills and knowledge needed to succeed in education and society, but that process will be enhanced when both the individual and structural realities of students' lives are the grist from which our lessons emerge.

And finally, students need a curriculum that provides a window (Christensen, 2009; Erickson, 2007) into a present and a future they may not have imagined for themselves. These may be new academic and professional trajectories that have not readily been in their vision. Even more, however, the window a socially just curriculum can offer will engage students in exploration of their own agency as they learn to "see that history is not inevitable, that there are spaces where it can bend, change, and become more just" (Christensen, 2009, p. 6) and that they can become actors in that process. Curriculum as a window will help students see that they are capable of becoming proactive subjects, not passive objects, in the processes of history (Freire, 1970); they are capable of becoming "justice-oriented citizens" (Westheimer \& Kahne, 2004).

This curriculum as window leads students to problem-pose the ordinary, taken-for-granted events of life that are, in fact, hegemonic expressions of oppression (Freire, 1970; Giroux, 1988; Kincheloe, 2005; McLaren, 2003). Emotionally volatile topics such as racism, sexism, and classism are incorporated into the curriculum as students are encouraged to challenge and "talk back" to textual authority and permission has been granted for this version to appear in e-Publications@Marquette. SAGE Publications does not grant permission for this article to be further copied/distributed or hosted elsewhere without the express permission from SAGE Publications. 
status quo in their own lives, in the schools, and in their communities (Christensen, 2009; Edelsky, 1999). Greene (1998) argues that solid academic knowledge, though important, will not guarantee that students grow up to become "principled enough, committed enough to reach beyond their self-interest and take responsibility for what happens in the space between themselves and others, what has been called the public space" (p. xxxiv). In Greene's recommendation, all students need to be exposed to the particulars of societal injustice that can pierce apathy and provoke the empathy and outrage needed to prompt them to act for the betterment of society.

One strategy to help preservice teachers explore a curriculum that includes controversial topics and possible student responses is a role-play of various stakeholders, each with a different position. In this activity, preservice teachers read examples of lessons using critical topics such as racism or sexism (see Bigelow et al., 2001; Christensen, 2009), and on the day of class, I set up a coffee shop, complete with home-baked banana bread. A group of preservice teachers choose roles of teacher, principal, student, or parent, along with positions toward this type of critical curriculum: in favor, ambivalent, or opposed. They gather around the table, eat the food, and discuss the pros and cons from their stakeholders' perspective. Any other preservice teacher can enter the coffee shop at any time, selecting any role and position (or introducing new ones-one student joined the discussion as a former president of the United States, another as the town mayor, a third as a local businessman), and contribute to the conversation. At the end, we list and discuss the issues that surfaced, and students then write a reflective journal exploring where they see themselves in relation to this type of curriculum. The result frequently has been a more complex understanding of this aspect of socially just teaching, gained from trying on and exploring multiple perspectives.

Although this curricular aspect clearly focuses on structural-level issues and activism, the effects it can produce on the academic success of individual students are also manifestations of justice. Drawing on years of classroom experience, Christensen (2009) claims that "students rise to the challenge of a rigorous curriculum about important issues if that rigor reflects the real challenges in their lives" (p. 8). Although no level of creative engagement with a social justice-

Journal of Teacher Education, Vol. 61, No. 3 (May/June 2010): pg. 197-210. DOI. This article is (C SAGE Publications and permission has been granted for this version to appear in e-Publications@Marquette. SAGE Publications does not grant permission for this article to be further copied/distributed or hosted elsewhere without the express permission from SAGE Publications. 
oriented curriculum can take the place of students learning to read, write, and do math and science proficiently, academic engagement and, concurrently, student learning are frequently improved with a curriculum of important ideas and students' real experiences.

Christensen (2009) describes the vibrancy and quality of her students' writing and their willingness to grapple with grammar, vocabulary, and literary devices when their work "[reclaims] any part of our lives that society has degraded, humiliated, or shamed" (p. 15). Any teacher who has risked moving his or her curriculum into the realm of the real world has witnessed the difference between the quality of student work done on reading, writing, math, and science exercises, aimed at artificial school audiences, and the quality of work produced when doing authentic reading, writing, math, and science work, done for meaningful purposes, targeted to a real audience in society. When a socially just curriculum provides students with a mirror, tool kit, and window, built on the realities of their lives as well as structural, sociocultural realities, the possibility of successfully supporting academic development increases.

\section{Outside the Classroom}

Finally, the teacher's role as an advocate and activist is one more component of teaching for social justice (Giroux, 1988; Kincheloe, 2005; McLaren, 2003). At the school level, this means active engagement in analysis, critique, and challenge of those aspects of schooling that may be reproducing inequitable learning experiences. Every aspect of the educational system-teacher demographics, instructional strategies, curriculum, textbooks, disciplinary practices, testing and tracking policies, retention practices, graduation rates-is fair game for critique and activism, a reality made more clear when socially just educators use a structural orientation to analyze the profession (Carlisle et al., 2006; Nieto, 2000).

The vision of the socially just educator extends beyond the school, however. Wherever societal policies and practices oppress students, limiting their life opportunities and, consequently, the quality of their learning experience, socially just teachers are called to act as advocates and activists, seeking reform to redress the inequity (Carlisle et al., 2006). Though this is the most controversial aspect of

Journal of Teacher Education, Vol. 61, No. 3 (May/June 2010): pg. 197-210. DOI. This article is (C SAGE Publications and permission has been granted for this version to appear in e-Publications@Marquette. SAGE Publications does not grant permission for this article to be further copied/distributed or hosted elsewhere without the express permission from SAGE Publications. 
the definition of socially just teaching proposed in this essay, when teachers who long to provide their individual students with equitable access to learning start to recognize that those very students are many times trapped in structures that perpetuate inequity, even for generations, the response of activism and advocacy will make reasonable sense.

Individual teachers who consider this vision of activist to transform structurally imposed inequities, however, will find themselves grappling with their own individual level of gifting and energy. Not all have the resources or talents to effect systemic change. Although some will function as activists and advocates, others will find their strengths better expressed in more direct services to students in their classrooms. To help my preservice teachers explore this reality, we discuss a continuum of work in the service of justice in education. At one end of the continuum are private, individual acts of mercy or service to meet the needs of each individual child. At the other are collective, public acts of advocacy and reform to address inequitable structures and policies. Though a binary, either-or depiction of anything is inherently flawed, this continuum, with all the points along the way, helps students reflect on their personal strengths and limitations. As with other assignments and activities, the preservice teachers write a reflective journal discussing where they see themselves on this continuum at the present and where they project they may be in 5 to 10 years. This projection into the future is a crucial part of the assignment because preservice teachers' ability to grapple with these issues is developmental and their professional trajectory over time will clearly be developmental as well. Planting the seed of possible growth and creating a schema that allows for some of them to develop into activist roles are important parts of our input as teacher educators.

The key to effective social justice education, then, is not uniform responses from all teachers but rather collaborative approaches where each teacher acts for justice using his or her abilities while offering emotional and collegial support to others whose gifting allows them to act for justice in a different realm. One will stand before the school board to argue for policy revisions; another will kneel to explain fractions to a struggling student. These teachers are not operating in

Journal of Teacher Education, Vol. 61, No. 3 (May/June 2010): pg. 197-210. DOI. This article is (C SAGE Publications and permission has been granted for this version to appear in e-Publications@Marquette. SAGE Publications does not grant permission for this article to be further copied/distributed or hosted elsewhere without the express permission from SAGE Publications. 
opposition to each other; their efforts for justice are complementary. A commonly envisioned and mutually supported effort, expressed through each individual's gifts in both structural and individual manifestations, is critical to the task before us because no aspect of socially just teaching is "an individual effort" (Christensen, 2009, p. 9). We cannot afford to siphon energies into mistrust and argument over the meaning of social justice when we need the different gifting each teacher brings to the pursuit of justice. All our efforts and the shared validation of all are necessary for success.

\section{Conclusion: Collaborative Efforts}

Preservice teachers clearly need dispositions of fairness, which many do possess (Chubbuck et al., 2007), and the belief that all children can learn. Negotiating the complex path from dispositions to socially just practice requires that our professional reflection be informed by both individual and structural analytical orientations. The individual lens is more commonly found; the structural less so (Cochran-Smith et al., 2009; Chubbuck et al., 2007; Whipp \& Chubbuck, 2009; Zeichner, 2006). In explicating the pathway connecting dispositions, professional reflection, and teacher behaviors, the framework in this essay offers a more balanced emphasis on both orientations.

Clearly, socially just teaching is complex in both theory and implementation; human responses to injustice are equally, if not more, complex. Neither this framework nor any other can provide a failsafe antidote to deficit views of students or an assurance of effective socially just practice. Teaching pre-service teachers to use both an individual and a structural orientation in their professional reflection, however, can open up the possibility of more ways to understand student learning and, consequently, more methods to improve that learning. That wider vision of possibility may be a positive move toward reclaiming the term teaching for social justice and creating a schema to support educators in locating, understanding, and implementing a more efficacious socially just practice.

Much work remains, however. Longitudinal research to track how using both individual and structural orientations affects classroom

Journal of Teacher Education, Vol. 61, No. 3 (May/June 2010): pg. 197-210. DOI. This article is @ SAGE Publications and permission has been granted for this version to appear in e-Publications@Marquette. SAGE Publications does not grant permission for this article to be further copied/distributed or hosted elsewhere without the express permission from SAGE Publications. 
practice and student learning is clearly needed. This study can be done by examining the reflective processes of inservice teachers who are successful in a socially just practice. Another valuable approach would be studying the developmental transition of novice teachers using this individual and structural framework as they enter the profession. Also needed is systematic study, beyond the self-study of individual teacher educators, of the efficacy of teacher education units that apply both an individual and a structural lens in their instruction. A dialogue where teacher educators share the successes and failures of various strategies and approaches they have used to instruct preservice teachers in the use of both individual and structural orientations would be valuable. Indeed, honest discussion of our personal struggles as teacher educators to adopt and act on both individual and structural analyses would be helpful to the profession.

The goals of socially just education -those policies and practices that will improve the life and learning opportunities of all students by equipping them and working with them to create a more just, humane world-are too valuable to be lost in the muddied confusion and divisiveness that currently surround the term. This essay attempts to offer greater clarity of understanding and practice and, in so doing, invites the collaboration, research, and dialogue needed to advance our goals.

\section{Notes}

${ }^{1}$ Marquette University, Milwaukee, WI

\section{Declaration of Conflicting Interests}

- The author declared no potential conflicts of interest with respect to the authorship and/or publication of this article.

\section{Financial Disclosure/Funding}

- The author received no financial support for the research and/or authorship of this article.

\section{Corresponding Author}

- Sharon M. Chubbuck, Marquette University, College of Education, Educational Leadership and Policy Studies Department, Milwaukee, WI 53201 Email: Sharon.chubbuck@marquette.edu

Journal of Teacher Education, Vol. 61, No. 3 (May/June 2010): pg. 197-210. DOI. This article is (C SAGE Publications and permission has been granted for this version to appear in e-Publications@Marquette. SAGE Publications does not grant permission for this article to be further copied/distributed or hosted elsewhere without the express permission from SAGE Publications. 
NOT THE PUBLISHED VERSION; this is the author's final, peer-reviewed manuscript. The published version may be accessed by following the link in the citation at the bottom of the page.

\section{About the Author}

- Sharon M. Chubbuck is an associate professor of educational policy and leadership studies at Marquette University in Milwaukee, WI.

\section{References}

Au, K. H., Mason, J. M., \& Scheu, J. A. (1995). Literacy instruction today. New York: HarperCollins.

Banks, J. (2007a). Approaches to multicultural curriculum reform. In J. Banks \& C. M. Banks (Eds.), Multicultural education: Issues and perspectives (6th ed., pp. 247-269). Hoboken, NJ: John Wiley.

Banks, J. (2007b). Multicultural education: Characteristics and goals. In J. Banks \& C. M. Banks (Eds.), Multicultural education: Issues and perspectives (6th ed., pp. 3-30). Hoboken, NJ: John Wiley.

Berlak, A. (2004). Confrontation and pedagogy: Cultural secrets and emotion in anti-oppressive pedagogies. In M. Boler (Ed.), Democratic dialogue in education: Troubling speech, disturbing silence (pp. 123-144). New York: Peter Lang.

Biddle, B. J., \& Berliner, D. C. (2002). School funding in the United States. Educational Leadership, 59(8), 48-59.

Bigelow, B., Harvey, B., Karp, S., \& Miller, L. (Eds.). (2001). Rethinking our classrooms: Teaching for equity and justice (Vol. 2). Milwaukee, WI: Rethinking Schools.

Boler, M., \& Zembylas, M. (2003). Discomforting truths: The emotional terrain of understanding differences. In P. Tryfonas (Ed.), Pedagogies of difference: Rethinking education for social justice (pp. 110-136). New York: Routledge.

Braddock, J. H. (1995). Tracking and school achievement: Implications for literacy development. In V. L. Gadsden \& D. A. Wagner (Eds.), Literacy among African-American youth: Issues in learning, teaching, and schooling (pp. 177-200). Cresskill, NJ: Hampton Press.

Burant, T. J., Chubbuck, S. M., \& Whipp, J. L. (2007). Reclaiming the moral in the dispositions debate. Journal of Teacher Education, 58(5), 397-411.

Carlisle, L. R., Jackson, B. W., \& George, A. (2006). Principles of social justice education: The social justice education in schools project. Equity \& Excellence in Education, 39, 55-64.

Christensen, L. (2009). Teaching for joy and justice. Milwaukee, WI: Rethinking Schools.

Chubbuck, S. M. (2001). Rejecting White racist ideology: Holistic, psychological, and sociological factors operating in the life and practice of two White European American literacy teachers. Unpublished doctoral dissertation, University of Illinois, Urbana-Champaign.

Journal of Teacher Education, Vol. 61, No. 3 (May/June 2010): pg. 197-210. DOI. This article is (C SAGE Publications and permission has been granted for this version to appear in e-Publications@Marquette. SAGE Publications does not grant permission for this article to be further copied/distributed or hosted elsewhere without the express permission from SAGE Publications. 
NOT THE PUBLISHED VERSION; this is the author's final, peer-reviewed manuscript. The published version may be accessed by following the link in the citation at the bottom of the page.

Chubbuck, S. M. (2004). Whiteness enacted, Whiteness disrupted: The complexity of personal congruence. American Educational Research Journal, 4(2), 301-333.

Chubbuck, S. M. (2008). A novice teacher's beliefs about socially just teaching: Dialogue of many voices. New Educator, 4(4), 309-329. Chubbuck, S. M., Burant, T., \& Whipp, J. (2007). The presence and possibility of moral sensibility in beginning preservice teachers. Ethics and Education, 2(2), 109-130.

Chubbuck, S. M., \& Zembylas, M. (2008). The emotional ambivalence of socially just teaching: A case study of a novice urban school teacher. American Educational Research Journal, 45(2), 274-318.

Cochran-Smith, M. (2003). Conceptual framework for multicultural teacher education: A conceptual framework. Teacher Education Quarterly, $30(2), 7-25$.

Cochran-Smith, M. (2004). Walking the road: Race, diversity, and social justice in teacher education. New York: Teachers College Press.

Cochran-Smith, M., Shakman, K., Jong, C., Terrell, D. G., Barnatt, J., \& McQuillan, P. (2009). Good and just teaching: The case for social justice in teacher education. American Journal of Education, 115(3), 347.

Collier, V. P., \& Thomas, W. P. (2004). The astounding effectiveness of dual language education for all. NABE Journal of Research and Practice, 2(1), 1-20.

Damon, W. (2005). Personality test: The dispositional dispute in teacher preparation today, and what to do about it. Retrieved from http://www.edexcellence.net/detail/news.cfm?news_id=343

Darling-Hammond, L. (2004). Learning to teach for social justice. In L. Darling-Hammond, J. French, \& S. Garcia-Lopez (Eds.), Learning to teach for social justice (pp. 1-7). New York: Teachers College Press.

Delpit, L. (1995). Other people's children: Cultural conflict in the classroom. New York: New Press.

Diez, M. (2007). Looking back and moving forward: Three tensions in teacher dispositions discourse. Journal of Teacher Education, 58(5), 388-396.

Dlamini, S. N. (2002). From the other side of the desk: Notes on teaching about race when racialized. Race, Ethnicity, and Education, 5, 51-66.

Dottin, E. S. (2009). Professional judgment and dispositions in teacher education. Teaching and Teacher Education, 25(1), 83-88.

Edelsky, C. (1999). Making justice our project. Urbana, IL: National Council of Teachers of English.

Erickson, F. (2007). Culture in society and in educational practices. In J. Banks \& C. M. Banks (Eds.), Multicultural education (6th ed., pp. 3361). Hoboken, NJ: John Wiley.

Journal of Teacher Education, Vol. 61, No. 3 (May/June 2010): pg. 197-210. DOI. This article is @ SAGE Publications and permission has been granted for this version to appear in e-Publications@Marquette. SAGE Publications does not grant permission for this article to be further copied/distributed or hosted elsewhere without the express permission from SAGE Publications. 
NOT THE PUBLISHED VERSION; this is the author's final, peer-reviewed manuscript. The published version may be

accessed by following the link in the citation at the bottom of the page.

Freire, P. (1970). Pedagogy of the oppressed. New York: Herder and Herder. Gamoran, A. (1992). Synthesis of research: Is ability grouping equitable? Educational Leadership, 5(2), 11-17.

Garcia, G. E., \& Pearson, P. D. (1991). The role of assessment in a diverse society. In E. H. Hiebert (Ed.), Literacy in a diverse society: Perspectives, practices, and policies (pp. 253-278). New York: Teachers College Press.

Gershman, J. (2005). "Disposition" emerges as issue at Brooklyn College. Retrieved from http://www.nysun.com/article/14604

Giroux, H. A. (1988). Teachers as intellectuals: Toward a critical pedagogy of learning. Westport, CT: Bergin and Garvey.

Glenn, D. (2007, May 4). Education scholars debate social justice. Chronicle of Higher Education. Retrieved from http://chronicle.com/article/Education-Scholars-Debate/35722/

Greene, M. (1998). Introduction: Teaching for social justice. In W. Ayers, J. A. Hunt, \& T. Quinn (Eds.), Teaching for social justice (pp. xxvii-xlvi). New York: New Press.

Heath, S. B. (1982). Questioning at home and school: A comparative study. In G. Spindler (Ed.), Doing the ethnography of schooling: Educational anthropology in action (pp. 102-131). New York: Holt, Rinehart \& Winston.

Kincheloe, J. L. (2005). Critical pedagogy. New York: Peter Lang.

Kozol, J. (1991). Savage inequalities: Children in America's schools. New York: Crown.

Ladson-Billings, G. (1994). The dreamkeepers: Successful teachers of AfricanAmerican children. San Francisco: Jossey-Bass.

Landsman, J. (2009). A White teacher talks about race. Lanham, MD: Rowman \& Littlefield.

Lee, C. D. (2007). Culture, literacy, and learning. New York: Teachers College Press.

Leo, J. (2005, October 24). Class(room) warriors. U.S. News \& World Report. Retrieved from http://www.usnews.com/usnews/opinion/articles/051024/24john.htm

Lipman, P. (1997). Restructuring in context: A case study of teacher participation and the dynamics of ideology, race, and power. American Educational Research Journal, 34(1), 3-38.

McLaren, P. (2003). Life in schools: An introduction to critical pedagogy in the foundations of education (4th ed.). Boston: Allyn \& Bacon.

Moll, L. C. (1994). Literacy research in community and classrooms: A sociocultural approach. In R. B. Ruddell, M. R. Ruddell, \& H. Singer (Eds.), Theoretical models and processes of reading (pp. 179-207). Newark, DE: International Reading Association. National Council for Accreditation of Teacher Education. (2006).

Journal of Teacher Education, Vol. 61, No. 3 (May/June 2010): pg. 197-210. DOI. This article is (C SAGE Publications and permission has been granted for this version to appear in e-Publications@Marquette. SAGE Publications does not grant permission for this article to be further copied/distributed or hosted elsewhere without the express permission from SAGE Publications. 
NOT THE PUBLISHED VERSION; this is the author's final, peer-reviewed manuscript. The published version may be accessed by following the link in the citation at the bottom of the page.

Professional standards for the accreditation of schools, colleges, and departments of education: 2006 edition. Retrieved from http://www.ncate.org/documents/standards/unit_stnds_2006.pdf

National Council for Accreditation of Teacher Education. (2009). Glossary. Retrieved June 30, 2009, from http://ncate.org/public/glossary.asp?ch=4

Nieto, S. (2000). Placing equity front and center. Journal of Teacher Education, 51(3), 180-187.

North, C. (2006). More than words? Delving into the substantive meaning(s) of "social justice" in education. Review of Educational Research, 76(4), 507-535.

Novak, M. (2000). Defining social justice. First Things, 108, 11-13. Retrieved from http://www.firstthings.com/ftissues/ft0012/opinion/novak.html

Oakes, J. (1985). Keeping track: How schools structure inequality. New Haven, CT: Yale University Press.

Parker, W. C. (2005). Teaching against idiocy. Phi Delta Kappan, 86(5), 344352.

Perry, T., \& Delpit, L. (1998). The real Ebonics debate. Boston: Beacon.

Powers, E. (2006). A spirited disposition debate. Inside Higher Education. Retrieved from http://insidehighered.com/news/2006/06/06/disposition

Prager, D. (2005). The Left's original sin. FrontPageMagazine.com. Retrieved from http://97.74.65.51/readArticle.aspx?ARTID =7196

Rich, A. (1986). Blood, bread and poetry. Retrieved from http://www.poemhunter.com/adrienne-rich/quotations/page-8/

Rickford, J. (1997). Letter to Senator Spector. Retrieved from http://www.stanford.edu/ rickford/ebonics/SpecterLetter.html

Shulman, L. (1986). Those who understand: Knowledge growth in teaching. Educational Researcher, 2(15), 4-14.

Sockett, H. (2009, February). Dispositions as virtues: The complexity of the construct. Paper presented at the meeting of the American Association of Colleges for Teacher Education, Chicago.

Steele, C.M. (1997). A Threat in the air: How stereotypes shape intellectual identity and performance. American Psychologist, 52(6), 613-629.

Stern, S. (2006). The Ed Schools' Latest-and Worst-Humbug. City Journal. Retrieved from http://www.city-journal.org/html/16_3_ed_school.html

Taylor, H. (1989). Standard English, Black English, and bidialectalism. New York: Peter Lang.

West, C. (1993). Race Matters. New York: Vintage. Westheimer, J., \& Kahne, J. (1998). Education for action: Preparing youth for participatory democracy. In W. Ayers, J. A. Hunt, \& T. Quinn (Eds.), Teaching for social justice (pp. 1-19). New York: New Press.

Journal of Teacher Education, Vol. 61, No. 3 (May/June 2010): pg. 197-210. DOI. This article is (C SAGE Publications and permission has been granted for this version to appear in e-Publications@Marquette. SAGE Publications does not grant permission for this article to be further copied/distributed or hosted elsewhere without the express permission from SAGE Publications. 
NOT THE PUBLISHED VERSION; this is the author's final, peer-reviewed manuscript. The published version may be accessed by following the link in the citation at the bottom of the page.

Westheimer, J., \& Kahne, J. (2004). What kind of citizen? The politics of educating for democracy. American Educational Research Journal, 4(2), 237-269.

Wheeler, R. S., \& Swords, R. (2006). Code-switching: Teaching standard English in urban classrooms. Urbana, IL: National Council of Teachers of English.

Whipp, J. L., \& Chubbuck, S. M. (2009, April). Developing moral sensibility in an urban teacher preparation program. Paper presented at annual meeting of the American Educational Research Association, San Diego, CA.

Wiggins, G., \& McTighe, J. (2005). Understanding by design. Alexandria, VA: Association for Supervision and Curriculum Development.

Will, G. (2006, January 16). Ed schools vs. education. Newsweek. Retrieved March 27, 2009, from http://www.msnbc.msn.com/id/10753446/site/newsweek/print/1/displ aymode/1098

Wise, A. (2005, November 14). Editorial opinion: Teacher Standards. U.S. News \& World Report, 13(18), 12-16.

Wise, A. (2006, February 28). NCATE News: Wise to Hess, Will, and Leo. Retrieved from http://www.ncate.org/public/0228_postWise.asp?ch $=150$

Zeichner, K. (2006). Reflections of a university-based teacher educator on the future of college- and university-based teacher education. Journal of Teacher Education, 57(3), 326-340.

Zembylas, M., \& Chubbuck, S. (in press-a). Emotions and social inequalities: Mobilizing emotions for social justice education. In P. Schutz \& M. Zembylas (Eds.), Advances in teacher emotion research: The impact on teachers' lives. Dordrecht, Netherlands: Springer.

Zembylas, M., \& Chubbuck, S. M. (2009). Teachers' emotions in times of change in Europe: Exploring teachers' emotional experiences and social justice education. In D. Liston \& C. Day (Eds.), International handbook on teacher and school development. New York: Routledge.

Journal of Teacher Education, Vol. 61, No. 3 (May/June 2010): pg. 197-210. DOI. This article is (C SAGE Publications and permission has been granted for this version to appear in e-Publications@Marquette. SAGE Publications does not grant permission for this article to be further copied/distributed or hosted elsewhere without the express permission from SAGE Publications. 


\section{Appendix}

Figure 1

Rudimentary professional reflection on cause and solution of student learning difficulty

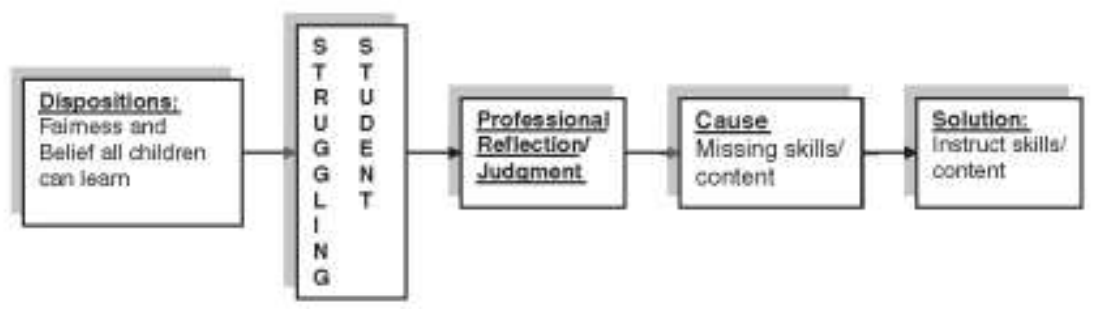

Figure 2

Professional reflection on cause and solution of student learning difficulty using individual orientation

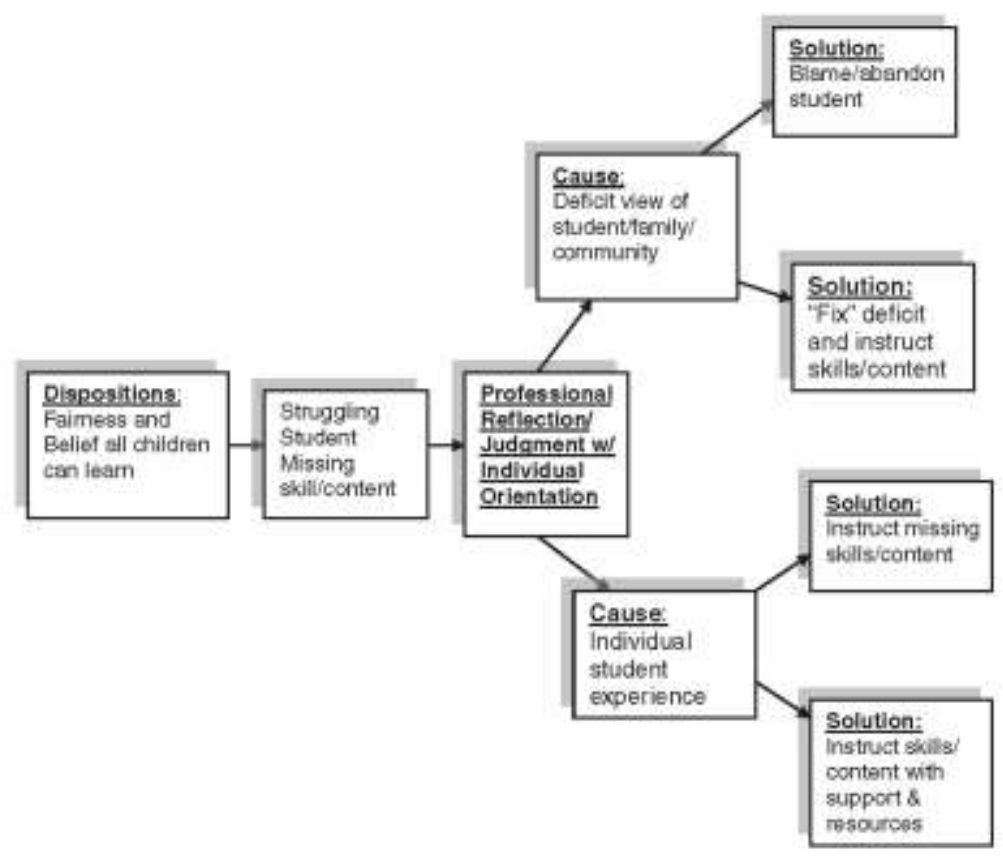

Journal of Teacher Education, Vol. 61, No. 3 (May/June 2010): pg. 197-210. DOI. This article is (C SAGE Publications and permission has been granted for this version to appear in e-Publications@Marquette. SAGE Publications does not grant permission for this article to be further copied/distributed or hosted elsewhere without the express permission from SAGE Publications. 
NOT THE PUBLISHED VERSION; this is the author's final, peer-reviewed manuscript. The published version may be accessed by following the link in the citation at the bottom of the page.

\section{Figure 3}

Professional reflection on cause and solution of student learning difficulty using both individual and structural orientations

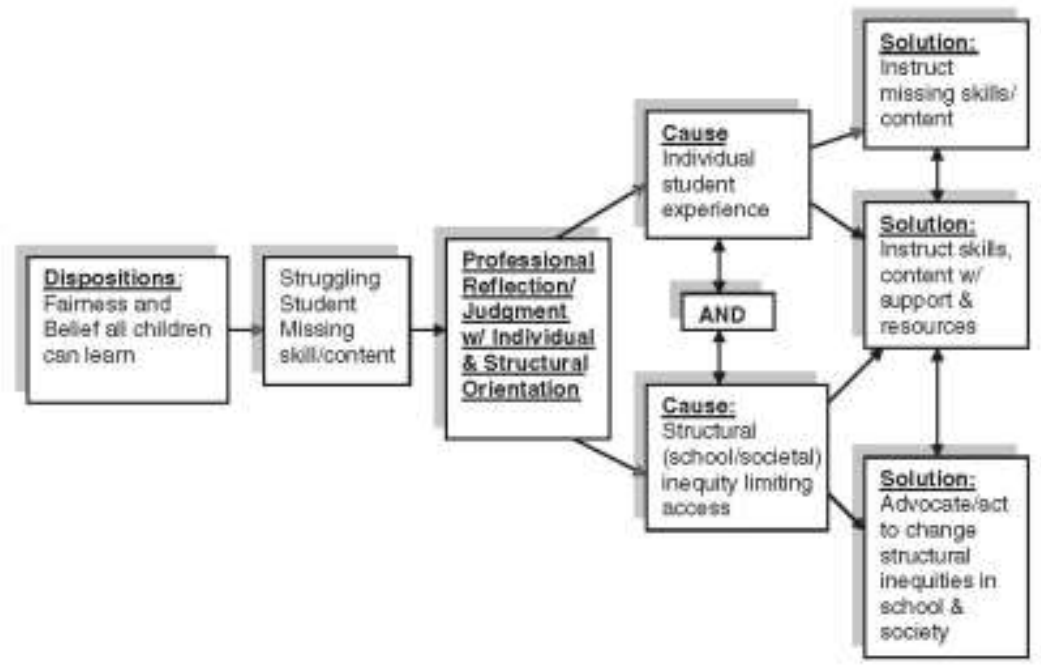

Journal of Teacher Education, Vol. 61, No. 3 (May/June 2010): pg. 197-210. DOI. This article is (C SAGE Publications and permission has been granted for this version to appear in e-Publications@Marquette. SAGE Publications does not grant permission for this article to be further copied/distributed or hosted elsewhere without the express permission from SAGE Publications. 